\title{
Formulation design and characterization of a non-ionic surfactant based vesicular system for the sustained delivery of a new chondroprotective agent
}

\author{
Muhammad Imran Khan, Asadullah Madni*, Saeed Ahmad, Muhammad Ahmad Mahmood, \\ Mubashar Rehman, Muhammad Ashfaq
}

\author{
Department of Pharmacy, The Islamia University of Bahawalpur, Bahawalpur, Pakistan
}

\begin{abstract}
Diacerein is used for symptomatic relief and cartilage regeneration in osteoarthritis. Due to gastrointestinal side effects, poor aqueous solubility and low bioavailability, its clinical usage has been restricted. The objective of the present study was to enhance its dissolution profile and to attain sustained release by designing a novel delivery system based on niosomes. Five niosomal formulations $\left(\mathrm{F}_{1}-\mathrm{F}_{5}\right)$ with nonionic surfactant (sorbitan monostearate) and cholesterol in varying ratios of 5:5, 6:4, 7:3, 8:2 and 9:1 were developed by the reverse-phase evaporation technique. The size and polydispersivity index (PDI) were found in the range of $0.608 \mu \mathrm{m}$ to $1.010 \mu \mathrm{m}$ and 0.409 to 0.781 , respectively. Scanning electron microscopy (SEM) of the selected formulation $\left(\mathrm{F}_{3}\right)$ revealed spherical vesicles, and $79.8 \%$ entrapment was achieved with $F_{3}(7: 3)$. Dissolution studies using the dialysis method showed sustained release behaviour for all formulations. The optimized surfactant-to-cholesterol concentration (7:3) in formulation $\mathrm{F}_{3}$ sustained the drug-release time $\left(\mathrm{T}_{50 \%}\right)$ up to 10 hours. Kinetic modelling exhibited a zero-order release $\left(R^{2}=0.9834\right)$ and the release exponent ' $n$ ' of the Korsmayer-Peppas model $(n=0.90)$ confirmed non-fickian and anomalous release. The results of this study suggest that diacerein can be successfully entrapped into niosomes using sorbitan monostearate and that these niosomes have the potential to deliver diacerein efficiently at the absorption site.
\end{abstract}

Uniterms: Chondroprotective. Diacerein/dissolution profile. Diacerein/sustained release. Niosomes. Sorbitan monostearate. Reverse-phase evaporation.

A diacereína é usada para o alívio sintomático e para a regeneração da cartilagem na osteoartrite. Devido aos efeitos adversos gastrointestinais, baixa solubilidade aquosa e biodisponibilidade, o seu uso clínico tem sido restrito. O objetivo do presente estudo foi melhorar o perfil de dissolução deste fármaco e obter liberação prolongada através do planejamento de um novo sistema de liberação designado de niossoma. Cinco formulações distintas de niossomas $\left(\mathrm{F}_{1}\right.$ a $\left.\mathrm{F}_{5}\right)$ contendo tensoativos não iônicos (monoestearato de sorbitano) e colesterol, em diferentes proporções, de 5:5, 6:4, 7:3, 8:2 e 9:1, foram desenvolvidas através da técnica de evaporacão de fase reversa. Os tamanhos e índices de polidispersibilidade (PDI) obtidos variam entre 0,608 e 1,01 $\mu \mathrm{m}$ e entre 0,409 e 0,7781 , respectivamente. Imagens de microscopia electrônica de varrimento ( $\mathrm{SEM}$ ) da formulação selecionada $\left(\mathrm{F}_{3}\right)$ revelaram vesículas esféricas. Obteve-se encapsulação de 79,8\% com a formulação $\mathrm{F}_{3}$ (7:3). Estudos de dissolução usando o método de diálise demonstraram padrão de liberacão prolongada para todas as formulações. A proporção de tensoativo e colesterol (7:3) na formulacão $\mathrm{F}_{3}$ prolongou o tempo de liberação do fármaco (T50\%) até 10 horas. Estudos de modelação cinética demonstraram ordem de liberacão zero $\left(\mathrm{R}^{2}=0,9834\right)$ e o expoente de liberação "n" do modelo de Korsmayer-Peppas (n=0.90) confirmou a liberação não-fickiana e anômala. Os resultados deste estudo sugerem que a diacereína pode ser encapsulada com sucesso no interior de niossomas, utilizando monostearato de sorbitano, o qual tem potencial para liberar, eficientemente, a diacereína no local de absorção.

Unitermos: Condroprotetor. Diacereína/perfil de dissolução. Diacereína/liberação prolongada. Niossomas. Monoestearato de sorbitano. Evaporação em fase reversa.

\footnotetext{
*Correspondence: Dr. M. Asadullah Madni. Department of Pharmacy. Khawaja Fareed Campus. The Islamia University of Bahawalpur - 63100 - Bahawalpur, Pakistan. E-mail: asadpharmacist@hotmail.com
} 


\section{INTRODUCTION}

Vesicular systems, including liposomes and niosomes, are spherical configurations comprised of amphiphiles assembled into unilamellar or multilamellar structures. They are considered as cell-like bioreactors or primitive cell models and as suitable candidates for biomaterial encapsulation. Niosomes have prime importance in drug delivery as they can reduce toxicity, alter pharmacokinetics, enhance bioavailability and also sustain the release of the drug (Muzzalupo et al., 2008).

In the 1970s, niosomes were considered as a part of the cosmetic industry. The self-assembled nature of nonionic surfactants in an aqueous medium leads to the formation of a close concentric bilayer structural configuration, similar to that of liposomes but without phospholipids (Waddad et al., 2013). Niosomes have the ability to encapsulate hydrophilic drug moieties in the inner aqueous core and hydrophobic drugs into the bilayer structure (Hong et al., 2009). Niosomes have better stability, more convenient handling and storage conditions and are more cost effective than liposomes. These characteristics have attracted much attention in the field of drug delivery (Marianecci et al., 2012). Sorbitan fatty acid esters, alkyl ethers, alkyl glyceryl ethers and polyoxyethylene (4) lauryl ether (Brij 30) are extensively employed components of niosomal formulations (Mahale et al., 2012).

Osteoarthritis is a degenerating disease of tissues and cartilage that causes changes in biochemical properties of synovial fluid due to breakdown in joints by local protease enzymes (Pearle, Warren, Rodeo, 2005). Metabolic, developmental, traumatic and genetic diseases may elicit osteoarthritis and alter the functionality of particular joints, such as the spine, hands, hip and knee (Shari, Bathon, 2012). Diacerein is a new anthraquinone derivative that has analgesic and anti-inflammatory properties (Hunter, Wise, 2007). Clinical investigations have demonstrated that diacerein is an effective drug for the symptomatic relief of osteoarthritis (Nguyen et al., 1994). Diacerein is sparingly soluble in water (less than $0.01 \mathrm{mg} / \mathrm{ml}$ ) (Maski et al., 2009). Several formulation strategies have been employed to produce diacerein with an improved dissolution and hence bioavailability profile. Diacerein was complexed with PEG 6000 in solid dispersions and there was a marked improvement in its dissolution rate and solubility (Aggarwal, Singh, 2011). An attempt was made to encapsulate diacerein into solid lipid nanoparticles by modified high-shear homogenization using an ultrasonication technique and stearic acid as the main constituting agent. Stearic acid-based solid lipid nanoparticles were found to be promising carriers for diacerein (Jain et al., 2013). Polyvinyl pyrrollidone K30 (PVP-K30) and hydroxypropyl methylcellulose E4 (HPMC E4) have been employed to produce diacerein in a solid dispersion form to improve its solubility and dissolution rate (Deshmukh et al., 2010).

Limited data is available for the development of niosomal delivery systems for this chondroprotective agent. Therefore, the present study aimed to prepare a niosomal system to improve the solubility and thereby the bioavailability of diacerein by entrapping the drug in the vesicles of these systems. The added benefits are the low cost of formulation ingredients, easily operated methods, cost effectiveness, enhanced entrapment and retarded release of the drug.

\section{MATERIAL AND METHODS}

\section{Material}

Diacerein was received as a research material donation from Consolidated Chemical Laboratories (Pvt.) Ltd. Pakistan. Span 60 and cholesterol were purchased from Sigma Aldrich, UK. All solvents including ethanol (Sigma Aldrich), diethyl ether (Sigma Aldrich) and methanol were of HPLC grade (Sigma Aldrich). Distilled water was prepared fresh in the laboratory using distillation apparatus (Hamilton, England).

\section{Preparation of niosomes}

The niosomes were prepared using a reverse-phase evaporation method. The mixtures of surfactant and cholesterol in different molar ratios $(5: 5,6: 4,7: 3,8: 2$, $9: 1)$ were accurately weighed (Table I) and dissolved in $20 \mathrm{~mL}$ of chloroform/ethanol mixture $(2: 1 \mathrm{v} / \mathrm{v})$ separately. The organic solvents from all formulations were slowly evaporated under reduced pressure in a rotary evaporator (Heidolph, Germany) at $60^{\circ} \mathrm{C}$ until a smooth film of lipid components was formed on the wall of the rotating flask. The film was resuspended in $20 \mathrm{~mL}$ of ether. The drug solution $(1 \mathrm{mg} / \mathrm{mL})$ was prepared in a $15-\mathrm{mL}$ mixture $(2: 1)$ of phosphate-buffered saline (PBS; $\mathrm{pH}$ 7.4) and ethanol. The mixture of lipid solution and drug solution was sonicated for 5 minutes and swirled by hand and then sonicated again for 2 minutes in a bath sonicator. The resulting dispersion was immediately evaporated to disrupt the formed gel. Then, $10 \mathrm{ml}$ of PBS ( $\mathrm{pH}$ 7.4) was added to the rotating flask and the evaporation was continued for 15 minute to ensure the complete removal of the remaining diethyl ether. The niosomal suspension was refrigerated at $4{ }^{\circ} \mathrm{C}$ overnight to obtain the mature vesicles (Guinedi et al., 2005). 
TABLE I - Composition of different niosomal formulations

\begin{tabular}{ccccccc}
\hline $\begin{array}{c}\text { Formulation } \\
\text { Code }\end{array}$ & $\begin{array}{c}\text { Surfactant } \\
(\mathrm{mg})\end{array}$ & $\begin{array}{c}\text { Cholesterol } \\
(\mathrm{mg})\end{array}$ & $\begin{array}{c}\text { Molar ratio } \\
(\text { Surfactant: } \\
\mathrm{CHO})\end{array}$ & $\begin{array}{c}\text { Amount of drug } \\
(\mathrm{mg})\end{array}$ & $\begin{array}{c}\text { No of } \mu \text { moles } \\
\text { of drug }\end{array}$ & $\begin{array}{c}\text { Equivalent no. } \\
\text { of } \mu \text { mol of lipid } \\
\text { contents }\end{array}$ \\
\hline $\mathrm{F}_{1}$ & 86.2 & 77.33 & $5: 5$ & 15 & 40 & 400 \\
$\mathrm{~F}_{2}$ & 103.44 & 61.86 & $6: 4$ & 15 & 40 & 400 \\
$\mathrm{~F}_{3}$ & 120.68 & 46.98 & $7: 3$ & 15 & 40 & 400 \\
$\mathrm{~F}_{4}$ & 137.92 & 30.93 & $8: 2$ & 15 & 40 & 400 \\
$\mathrm{~F}_{5}$ & 155.16 & 15.46 & $9: 1$ & 15 & 40 & 400 \\
\hline
\end{tabular}

\section{Characterization of vesicles}

The developed niosomal formulations of diacerein with different molar ratios of Span 60 and cholesterol were characterized for vesicle size, morphology, polydispersity index (PDI) and entrapment efficiency.

\section{Fourier transform infrared (FTIR) spectroscopic studies}

The compatibility of the drug and other formulation components were studied using FTIR (Bruker FTIR, Tensor 27Series, Germany). Spectra of individual niosomal components and formulations were measured using a pike single-bounce attenuated total reflectance (ATR) cell equipped with a ZnSe single crystal. For solid samples (pure drug, cholesterol), samples were added to the ATR cell and measured directly. For liquids (niosomal formulation), samples were placed directly on the small crystal spot and lever having concave surface is placed over it in order to prevent evaporation.

\section{Drug entrapment studies}

Diacerein-loaded niosomal formulations were ultracentrifuged at $14,800 \times \mathrm{g}$ for $1.5 \mathrm{~h}$ to separate the unentrapped drug from the niosomes. The concentration of free drug in the supernatant was estimated by measuring the absorbance at $258.50 \mathrm{~nm}$ using a UV spectrophotometer (IRMECO U2020, Germany). This process was repeated to ensure complete removal of the free drug. The amount of entrapped drug was determined by mathematical equation (1), as described elsewhere (Alsarra et al., 2005):

$\%$ Drug entrapment $=\frac{\text { Total drug }- \text { Drug in supernatant }}{\text { Total drug }} \times 100$

\section{Morphological study}

The morphological characteristics of niosomes were investigated using a field emission scanning electron microscope (JSM-7500F, Jeol, Japan). A drop of optimized niosomal formulation $\left(\mathrm{F}_{3}\right)$ was mounted on an aluminium stub with adhesive silver tape. The stubs were stored overnight under a vacuum and then sputter-coated using gold.

\section{Size and distribution measurements}

Size and polydispersivity index were measured by a dynamic light-scattering technique using a Zetasizer (ZS-90 Malvern Instruments, UK). For the measurements, vesicle dispersions were diluted 100 times with the same PBS ( $\mathrm{pH}$ 7.4) used for their preparation to avoid multiscattering of light. Buffer solutions were filtered through $0.45-\mu \mathrm{m}$ cellulose filters to remove impurities. Vesicle mean size and size distribution (PDI) were determined at $25^{\circ} \mathrm{C}$ while keeping the scattering angle at $90^{\circ}$. The instrument was operated at medium refractive index 1.330 , a medium viscosity of $1.0 \mathrm{mPa} . \mathrm{s}$ and dielectric constant of 80.4. Sample mean size and PDI were measured using the third-order cumulant fitting autocorrelation function.

\section{Assessment of stability}

The ability of niosomes to retain the drug was assessed by storing the niosomal formulations at two different temperatures, i.e. refrigeration temperature $\left(4-8{ }^{\circ} \mathrm{C}\right)$ and ambient temperature $\left(25^{\circ} \mathrm{C} \pm 2{ }^{\circ} \mathrm{C}\right)$. Samples were stored in glass vials for 3 months and were withdrawn at regular time intervals. The entrapment efficiency of niosomal formulations was analysed in order to characterize stability profile.

\section{In vitro release studies}

A dialysis method was adopted for determination of the release profile of niosomal formulations $\left(\mathrm{F}_{1}-\mathrm{F}_{5}\right)$. 
Each formulation ( $1 \mathrm{ml}$ ) was added to a dialysis bag, clamped and placed in a beaker containing $200 \mathrm{~mL}$ of PBS maintained at $\mathrm{pH} 7.4$ and $37^{\circ} \mathrm{C} \pm 2{ }^{\circ} \mathrm{C}$, which acted as the receptor compartment, and continuous stirring was by a magnetic stirrer at $50 \mathrm{rpm}$. Samples were taken at various time-points for a period of 12 hours and assayed at $258.50 \mathrm{~nm}$.

\section{Release kinetic behaviour}

The release pattern of diacerein from the niosomal formulations $\left(\mathrm{F}_{1}-\mathrm{F}_{5}\right)$ was evaluated by applying different kinetic models to the observed release data to find the release mechanism. The following models were applied to the release data in order to assess the release mechanism from niosomes. The kinetic models (Dash et al., 2010) are given in equation 2, 3, 4 and 5 .

$$
\text { Zero order } Q_{t}=Q_{0}+K_{0}
$$

where $Q_{t}$ is the amount of drug released in time $t, Q_{0}$ is the initial amount of the drug in the solution, and $\mathrm{K}_{\mathrm{o}}$ is the zero-order release constant.

$$
\text { First Order } \quad \log C=\log \mathrm{Co}-\frac{\mathrm{Kt}}{2.303}
$$

where $\mathrm{C}_{\mathrm{o}}$ is the initial drug concentration, $\mathrm{t}$ is time, and $\mathrm{K}$ is the first-order release constant.

$$
\text { Higuchi model } Q=K_{H} \cdot t_{1 / 2}
$$

where $\mathrm{Q}$ is the amount of drug released in time $\mathrm{t}$, and $\mathrm{K}_{\mathrm{H}}$ is the Higuchi dissolution constant.

Moreover, in order to determine the release mechanism, the Korsemeyer-Peppas model was applied to all formulations:

$$
\text { Korsemeyer-Peppas Model } \frac{M_{t}}{M_{\infty}}=K t^{n}
$$

where $M_{t} / M_{\infty}$ is the amount of drug released at time t, $\mathrm{K}$ is the release rate constant, and $\mathrm{n}$ is the release exponent. The $\mathrm{n}$ value is used to characterize the different release mechanisms.

\section{Statistical analysis}

To compare the mean values of vesicle size and entrapment efficiencies of prepared niosomes and to assess statistical significance, a one-way analysis of variance (ANOVA) was performed at $95 \%$ confidence interval using SPSS 20.0.

\section{RESULTS AND DISCUSSION}

\section{Formation of niosomes}

The reverse-phase evaporation technique was found to be optimal for designing niosomes of diacerein. Formulations were prepared containing a total lipid mixture of $400 \mu \mathrm{mol}$ in the order of increasing surfactant and decreasing the cholesterol concentration. The surfactant and cholesterol were dissolved in a mixture of chloroform and ethanol. This organic solution was evaporated and mixed with the drug solution following sonication. The emulsion was again evaporated to remove traces of the organic solvent and hydration was continued at $60{ }^{\circ} \mathrm{C}$.

Due to its inherent characteristics, Span 60 was employed in this study. It is solid at room temperature, has a higher phase-transition temperature $\left(53-57^{\circ} \mathrm{C}\right)$ and an HLB value of 4.7. Moreover, it can form vesicles with or without cholesterol (Abdelkader et al., 2010). Surfactants with higher solubility and HLB are not able to organize into vesicles. Therefore, niosomes generally do not develop between HLB values of 14 and 17 (Girigoswami, Das, De, 2006). Cholesterol has been incorporated into formulations as a vesicle stabilizer and it also abolishes the gel-liquid transition of the niosomes making these less leaky. The finding of this study indicated that all ratios of Span 60 and cholesterol were able to develop niosomes due to the lipophilic nature of the Span 60 and higher efficiency of encapsulating hydrophobic drugs like diacerein.

\section{Size and polydispersivity index}

The size of the vesicles was found to be in the range of $0.5 \mu \mathrm{m}$ to $1 \mu \mathrm{m}$ (Table II). The comparatively small size of the niosomes is due to the low HLB value of Span 60 used in the present study. The size of niosomes increases with increasing values of HLB (Pardakhty, Varshosaz, Rouholamini, 2007). The smaller size of niosomes can be explained on the basis of the low HLB value of Span 60, which results in low surface free energy, which leads to relatively less uptake of water in the core, and hence to smaller niosomes (Yoshioka, Sternberg, Florence, 1994).

The size of the vesicles was affected significantly (ANOVA, $\mathrm{p}<0.05$ ) by altering the surfactant to cholesterol level in the formulations. These findings are in accordance with the results of niosomal encapsulation of oestradiol and mannitol (Essa, 2010). The size distribution of the formulations could be observed from the PDI, as shown in Table II, which indicates that all formulations $\left(\mathrm{F}_{1}-\mathrm{F}_{5}\right)$ 
are multidispersed systems. Among all five formulations, $\mathrm{F}_{3}$ showed the lowest value of PDI (0.409), which also favours the $\mathrm{F}_{3}$ formulation to be the more optimized.

TABLE II - Average size and polydispersivity index of the niosomal formulations

\begin{tabular}{ccc}
\hline Formulation Code & $\operatorname{Size}^{\mathrm{a}}(\mu \mathrm{m})$ & $\begin{array}{c}\text { Polydispersivity } \\
\text { Index }\end{array}$ \\
\hline $\mathrm{F}_{1}$ & $1010 \times 10^{-3} \pm 0.142$ & $0.476 \pm 0.04$ \\
$\mathrm{~F}_{2}$ & $987.1 \times 10^{-3} \pm 0.260$ & $0.504 \pm 0.14$ \\
$\mathrm{~F}_{3}$ & $965.7 \times 10^{-3} \pm 0.119$ & $0.409 \pm 0.17$ \\
$\mathrm{~F}_{4}$ & $835.9 \times 10^{-3} \pm 0.188$ & $0.632 \pm 0.05$ \\
$\mathrm{~F}_{5}$ & $608.4 \times 10^{-3} \pm 0.312$ & $0.781 \pm 0.21$ \\
\hline
\end{tabular}

Data are means $\pm S D ; p<0.05$. ${ }^{\text {a }}$ Size of niosomes was significantly different from each other according to the post-hoc test.

\section{Scanning electron microscopy}

The SEM image of the selected formulation $\left(\mathrm{F}_{3}\right)$ revealed the spherical shape of niosomes (Figure 1).

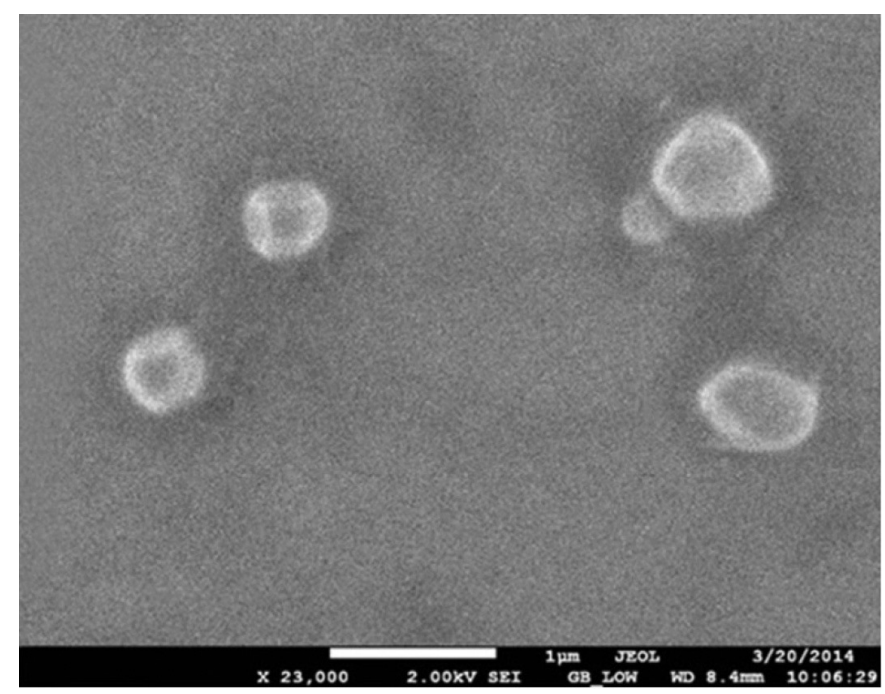

FIGURE 1 - SEM image of optimized formulation $\mathrm{F}_{3}$.

The shape of vesicles is predicted on the basis of the critical packing parameter (CPP), which is calculated from the area of the hydrophilic head group and the length of the alkyl chain of the surfactant by the following formula:

$$
C P P=\mathrm{v} / l c \cdot \alpha_{0}
$$

where $v$ is the lipophilic group volume, $1_{c}$ is the critical hydrophobic group length, and $\alpha_{0}$ is the area of the hydrophilic head group. Span 60 has a CPP value in the range of 0.5 to 1 and can give rise to niosomes (Uchegbu,
Vyas, 1998). The spherical shape of the niosomes obtained in our study is in agreement with previous reports of entrapping opioid antagonist naltrexone by sorbitan monostearate (Abdelkader et al., 2012) and also entrapment of calcein in the same surfactant (Manosroi et al., 2003).

\section{Drug entrapment studies}

The ultracentrifugation method was found to be suitable for the determination of entrapment efficiency of niosomal formulations $\left(\mathrm{F}_{1}-\mathrm{F}_{5}\right)$ as shown in Table III. The amount of entrapped drug was obtained by subtracting the amount of unentrapped drug from the total drug incorporated.

The entrapment efficiency was affected mainly by the molar concentration of cholesterol because the total molar concentration of the lipid content was kept constant (Table I) throughout the experiments. Previous studies have reached contrasting conclusions about the effect of the concentration of cholesterol on entrapment efficiency. Some reports describe that there was no effect of cholesterol concentration on niosomes entrapment efficiency (Uchegbu et al., 1995), while other studies show that entrapment efficiency increases with increasing cholesterol concentration from $0 \%$ to $50 \% \mathrm{~mol} / \mathrm{mol}$ (Yoshioka, Sternberg, Florence, 1994) and another report showed limited enhancement of entrapment efficiency up to $30 \% \mathrm{~mol} / \mathrm{mol}$ (Moazeni et al., 2010).

TABLE III - Average entrapment efficiency of the niosomal formulations

\begin{tabular}{ccc}
\hline $\begin{array}{c}\text { Formulation } \\
\text { Code }\end{array}$ & $\begin{array}{c}\text { Surfactant:cholesterol } \\
\text { ratio }(\mu \text { molar ratio })\end{array}$ & $\begin{array}{c}\text { \% Entrapment } \\
\text { efficiency }\end{array}$ \\
\hline $\mathrm{F}_{1}$ & $5: 5$ & $47.15 \pm 0.46$ \\
$\mathrm{~F}_{2}$ & $6: 4$ & $59.65 \pm 0.51$ \\
$\mathrm{~F}_{3}$ & $7: 3$ & $79.80 \pm 0.35$ \\
$\mathrm{~F}_{4}$ & $8: 2$ & $68.54 \pm 0.39$ \\
$\mathrm{~F}_{5}$ & $9: 1$ & $61.47 \pm 0.44$ \\
\hline
\end{tabular}

Data are means $\pm \mathrm{SD} ; \mathrm{p}<0.05 .{ }^{\mathrm{b}}$ Entrapment efficiency of all niosomal formulations was significantly different from each other according to the post-hoc test.

In our studies, entrapment efficiency was enhanced up to $30 \% \mathrm{~mol} / \mathrm{mol}$ concentration of cholesterol. In formulations $\mathrm{F}_{1}$ and $\mathrm{F}_{2}$, entrapment efficiency was lower than in formulation $\mathrm{F}_{3}$, which might be ascribed to the fact that higher concentrations of cholesterol may cause disruption of the vesicles leading to leakage of drug from 
TABLE IV - Stability of diacerein niosomes at different temperatures

\begin{tabular}{|c|c|c|c|c|c|c|c|c|c|c|}
\hline \multirow{3}{*}{ Month } & \multicolumn{5}{|c|}{ Temperature $4-8^{\circ} \mathrm{C}$} & \multicolumn{5}{|c|}{ Temperature $25^{\circ} \mathrm{C} \pm 2{ }^{\circ} \mathrm{C}$} \\
\hline & \multicolumn{5}{|c|}{ \% Entrapment Efficiency } & \multicolumn{5}{|c|}{$\%$ Entrapment Efficiency } \\
\hline & $\mathrm{F}_{1}$ & $\mathrm{~F}_{2}$ & $\mathrm{~F}_{3}$ & $\mathrm{~F}_{4}$ & $\mathrm{~F}_{5}$ & $\mathrm{~F}_{1}$ & $\mathrm{~F}_{2}$ & $\mathrm{~F}_{3}$ & $\mathrm{~F}_{4}$ & $\mathrm{~F}_{5}$ \\
\hline 0 & 47.1 & 59.65 & 79.80 & 68.54 & 62.47 & 47.1 & 59.65 & 79.80 & 68.54 & 62.47 \\
\hline 1 & 46.98 & 59.33 & 79.75 & 68.42 & 62.35 & 46.82 & 59.21 & 79.61 & 68.41 & 62.29 \\
\hline 2 & 46.70 & 59.12 & 79.35 & 68.23 & 62.08 & 46.60 & 59.05 & 79.19 & 68.11 & 61.95 \\
\hline 3 & 46.45 & 58.93 & 78.87 & 68.15 & 61.70 & 45.97 & 58.80 & 78.73 & 67.98 & 61.52 \\
\hline
\end{tabular}

the microenvironment of the vesicles, thus leading to comparatively low entrapment efficiency (Abdelkader et al., 2010). Formulation $\mathrm{F}_{3}$ had the highest entrapment efficiency $(79.80 \%)$ among all the formulations as it contained the optimized concentration of cholesterol. Formulations $\mathrm{F}_{4}$ and $\mathrm{F}_{5}$ had lower entrapment efficiency than $\mathrm{F}_{3}$, which might be correlated with the lower amounts of cholesterol as compared to $\mathrm{F}_{3}$ (Table III). Statistical analysis of the data given in Table III demonstrated that percentage entrapment efficiency was significantly dependent upon the surfactant to cholesterol level in the formulations (ANOVA; $\mathrm{p}<0.05$ ).

\section{Stability of niosomes}

The encapsulation efficiency of diacerein in the vesicles was determined at the end of each month. There was no significant change in entrapment efficiency for diacerein at two different temperatures after 3 months (Table IV). Therefore, niosomes may be an effective formulation to protect from drug leakage.

\section{FTIR studies}

The spectra of individual components and formulations of diacerein were recorded and provided in Figure 2. The FTIR spectrum of diacerein showed the principal peaks of diacerein at $1764.56 \mathrm{~cm}^{-1}(\mathrm{C}=\mathrm{O}$, ester $)$, $1677 \mathrm{~cm}^{-1}(\mathrm{C}=\mathrm{O}$ stretch $\mathrm{COOH}), 1188.89 \mathrm{~cm}^{-1}(\mathrm{C}-\mathrm{O}$ stretch, ester), $760.43 \mathrm{~cm}^{-1}$ ( $m$-substituted benzene) and $703.02 \mathrm{~cm}^{-1}$ (benzene). Such peaks of diacerein have also been reported elsewhere (Silverstein, Webster, Kiemle, 2005), which shows the purity of the diacerein sample and its free nature without any type of pharmacophore. In the spectrum of the Span 60, there were peaks of the hydroxyl group at $3390.20 \mathrm{~cm}^{-1}$, strong aromatic $-\mathrm{CH}_{3}$ group $2916.75 \mathrm{~cm}^{-1}$ and the strong $\mathrm{C}=\mathrm{O}$ ester bond at $1734.63 \mathrm{~cm}^{-1}$ (Li et al., 2008). Cholesterol showed peaks of the hydroxyl group at $3429.82 \mathrm{~cm}^{-1}$, strong aromatic stretching of $\mathrm{CH}=\mathrm{CH}$ at $2931.41 \mathrm{~cm}^{-1}$, and the strong $\mathrm{C}=\mathrm{O}$ bond of carboxylic acid at $1770.20 \mathrm{~cm}^{-1}$ (Reis, Winter, Zerda, 1996).

The FTIR spectrum of the selected niosomal formulation $\left(\mathrm{F}_{3}\right)$ demonstrated a slight shifting of the peaks and peaks were found to be remarkably diffused (Figure 2). No formation of any new peak was observed indicating that no chemical interaction occurred, and further smoothening of peaks depicted the strong physical interaction that led to the formation of niosomes.

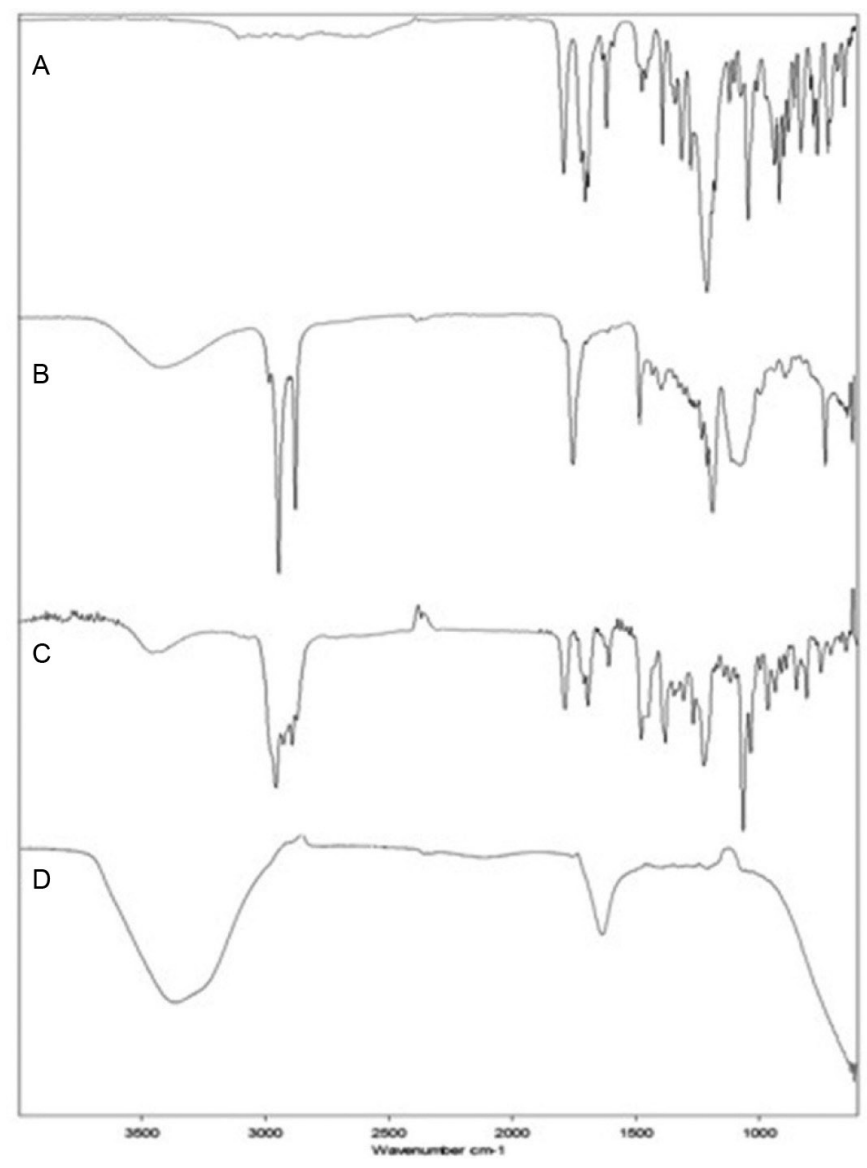

FIGURE 2 - FTIR Spectra of (A) diacerein, (B) sorbitan monostearate, $(\mathrm{C})$ cholesterol and $(\mathrm{D})$ niosomal formulation $\mathrm{F}_{3}$. 


\section{Release studies of niosomal formulations}

An overall sustained release behaviour was observed with all formulations $\left(\mathrm{F}_{1}-\mathrm{F}_{5}\right)$ as shown in Figure 3. The selected formulation $\left(\mathrm{F}_{3}\right)$ expressed more prolonged release and only $\sim 55 \%$ of the drug was released in the 12 -hour study design. The reason for this more retarded release from $\mathrm{F}_{3}$ was due to the optimum concentration of cholesterol in its vicinity, which provided the optimal strength and fluidity to the niosomes in a more efficient way.

Another reason is the reduction of the efflux of diacerein from niosomal vesicles by stabilizing the vesicular membrane and making it more rigid and less leaky (Demel, Dekruyff, 1976; Korchowiec et al., 2006). A similar phenomenon was observed with niosomeentrapped rifampicin, where the cholesterol was found to retard the release of the drug (Jain, Vyas, 1995). The slow release of drug from niosomes is also attributed to the use of Span 60, which has a slower rate of release than Span 20,80 and 85 , which in turn is due to the reason that Span 60 molecules remain in an ordered gel state, but other Spans are in a disordered liquid crystalline state (Attia et al., 2007).

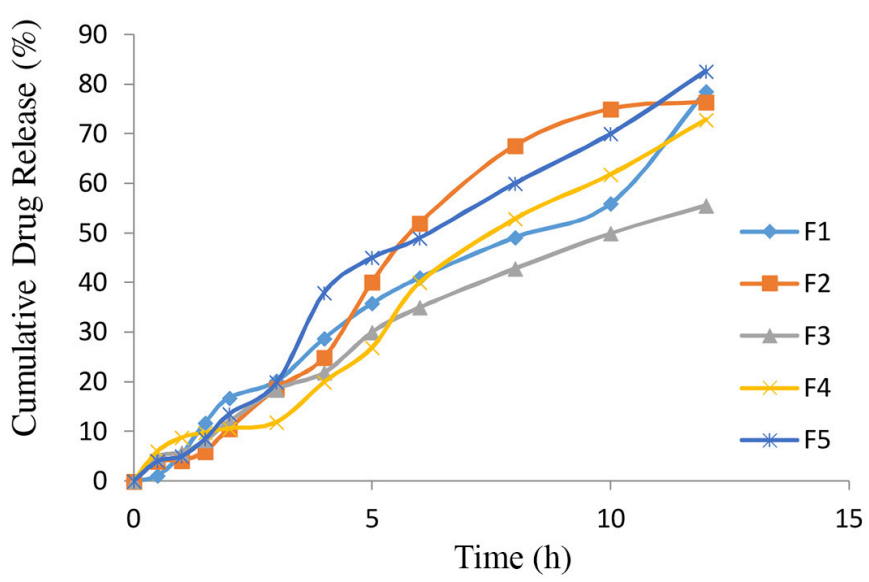

FIGURE 3 - Release profiles of niosomal formulations $\left(\mathrm{F}_{1}-\mathrm{F}_{5}\right)$.

\section{Release kinetic behaviour}

The regression coefficient $\left(r^{2}\right)$ values were approximated to follow zero-order release. Formulation $\mathrm{F}_{3}$ was the more optimized as it showed $\mathrm{r}^{2}=0.9834$. All equations including zero order, Higuchi model and Korsemeyer-Peppas equations, exhibited good linearity for the optimized selected formulation $\left(\mathrm{F}_{3}\right)$. The Korsemeyer-Peppas model was applied to all formulations data and the $n$ value was calculated. The value of $n$ for all formulations suggests non-fickian (anomalous) - i.e. coupling of both diffusion and erosion - mechanisms (Costa, Sousalobo, 2001). Table V gives the values of the rate constants and regression correlations using rate equations for the release of diacerein from niosomes. The overall results revealed that the zero-order $r^{2}$ values for all formulations were higher than the first-order values, which suggests that niosomal formulations $\left(\mathrm{F}_{1}-\mathrm{F}_{5}\right)$ can release the drug in sustained manner.

\section{CONCLUSION}

Niosomal formulations of Span 60 and cholesterol were successfully prepared by a reverse-phase evaporation method. Optimizing the concentration of cholesterol to an optimum level $\left(\mathrm{F}_{3}\right)$ increased the entrapment efficiency and sustained the release of diacerein from the niosomes. The formulation $\left(\mathrm{F}_{3}, 7: 3\right)$ showed maximum encapsulation efficiency $(79.80 \%)$ and a prolonged release profile $(55 \%)$ in 12 hours. The prepared niosomes can be used as potential carrier for the controlled release and enhanced availability of the diacerein at the site of absorption.

\section{ACKNOWLEDGEMENTS}

This study was a part of $\mathrm{PhD}$ thesis by Muhammad Imran Khan that was supported by the Higher Education Commission of Pakistan (Grant number: 112-238862BM1-354). The authors would like to thank the Chairman

TABLE V - Kinetic modelling of formulations $\left(\mathrm{F}_{1}-\mathrm{F}_{5}\right)$

\begin{tabular}{cccccccccc}
\hline \multirow{2}{*}{ Formulation } & \multicolumn{2}{c}{ Zero order } & \multicolumn{2}{c}{ First order } & \multicolumn{2}{c}{ Higuchi Equation } & \multicolumn{2}{c}{ Korsemeyer-Peppas } \\
\cline { 2 - 10 } & $\mathrm{r}^{2}$ & $\mathrm{~K}\left(\mathrm{~g} \mathrm{~h}^{-1}\right)$ & $\mathrm{r}^{2}$ & $\mathrm{~K}\left(\mathrm{~g} \mathrm{~h}^{-1}\right)$ & $\mathrm{r}^{2}$ & $\mathrm{~K}\left(\mathrm{~g} \mathrm{~h}^{-1}\right)$ & $\mathrm{r}^{2}$ & $\mathrm{~K}\left(\mathrm{~g} \mathrm{~h}^{-1}\right)$ & $\mathrm{n}$ \\
\hline $\mathrm{F}_{1}$ & 0.9815 & 7.357 & 0.6645 & 0.2790 & 0.9318 & 13.172 & 0.988 & 5.5716 & 0.9165 \\
$\mathrm{~F}_{2}$ & 0.9613 & 24.47 & 0.7885 & 0.1615 & 0.9036 & 13.0434 & 0.8648 & 5.844 & 0.8975 \\
$\mathrm{~F}_{3}$ & 0.9834 & 5.0275 & 0.7298 & 0.1357 & 0.9534 & 11.28 & 0.9915 & 6.615 & 0.9026 \\
$\mathrm{~F}_{4}$ & 0.9816 & 5.5603 & 0.9356 & 0.1235 & 0.883 & 12.47 & 0.9355 & 6.590 & 0.9997 \\
$\mathrm{~F}_{5}$ & 0.975 & 7.1075 & 0.7434 & 0.1717 & 0.9355 & 14.99 & 0.9727 & 8.183 & 0.9092 \\
\hline
\end{tabular}


of the Department of Pharmacy and the Vice Chancellor of The Islamia University of Bahawalpur for providing all the necessary facilities during the study.

\section{REFERENCES}

AGGARWAL, A.K.; SINGH, S. Physicochemical characterization and dissolution study of solid dispersions of diacerein with polyethylene glycol 6000. Drug Dev. Ind. Pharm., v.37, n.10, p.1181-1191, 2011.

ABDELKADER, H.; ISMAIL, S.; KAMAL, A.; ALANY, R. Preparation of niosomes as an ocular delivery system for naltrexone hydrochloride: physicochemical characterization. Pharmazie, v.65, n.11, p.811-817, 2010.

ABDELKADER, H.; WU, Z.; AL-KASSAS, R.; ALANY, R. Niosomes and discomes for oculardelivery of naltrexone hydrochloride: morphological, rheological, spreading properties and photo-protective effects. Int. J. Pharm., v.433, n.1, p.142-148, 2012.

ATTIA, I.A.; EL-GIZAWY, S.A.; FOUDA, M.A.; DONIA, A.M. Influence of a niosomal formulation on the oral bioavailability of acyclovir in rabbits. AAPS Pharm. Sci. Tech., v.8, n.4, p.E106, 2007.

ALSARRA, I.A.; BOSELA, A.A.; AHMED, S.M.; MAHROUS, G.M. Proniosomes as a drug carrier for transdermal delivery of ketorolac. Eur. J. Pharm. Biopharm., v.59, n.3, p.485490, 2005.

COSTA, P.; SOUSA LOBO, J.M. Modeling and comparison of dissolution profiles. Eur. J. Pharm. Sci., v.13, n.2, p.123133, 2001.

DESHMUKH, D.B.; GAIKWAD, P.D.; BANKAR, V.H.; PAWAR, S.P. Dissolution enhancement of poorly water soluble diacerein by solid dispersion technique. J. Pharm Sci. Res., v.2, n.11, p.734-739, 2010.

DASH, S.; MURTHY, P.N.; NATH, L.; CHOWDHURY, P. Kinetic modeling on drug release from controlled drug delivery systems. Acta Pol. Pharm., v.67, n.3, p.217-223, 2010.

DEMEL, R.A.; DEKRUYFF, B. The function of sterols in membranes. Biochim. Biophys Acta, v.457, n.2, p.109-132, 1976.
ESSA, E.A. Effect of formulation and processing variables on the particle size of sorbitan monopalmitate niosomes. Asian J. Pharm., v.4, n.4, p.227-233, 2010.

GIRIGOSWAMI, A.; DAS, S.; DE, S. Fluorescence and dynamic light scattering studies of niosomes membrane mimetic systems. Spectrochim. Acta. A. Mol. Biomol. Spectrosc., v.64, n.4, p.859-866, 2006.

GUINEDI, A.S.; MORTADA, N.D.; MANSOUR, S; HATHOUT, R.M. Preparation and evaluation of reverse phase evaporation and multilamellar niosomes as ophthalmic carriers of acetazolamide. Int. J. Pharm., v.306, n.1, p.71-82, 2005

HONG, M.; ZHU, S.; JIANG, Y.; TANG, G.; PEI, Y. Efficient tumor targeting of hydroxycamptothecin loaded PEGylated niosomes modified with transferrin. J. Control. Release, v.133, n.2, p.96-102, 2009.

HUNTER, D.J.; WISE, B. Review: diacerein is more effective than placebo. J. Evid. Based Med., v.12, n.3, p.74, 2007.

JAIN, A.; SINGH, S.K.; SINGH Y.; SINGH, S. Development of lipid nanoparticles of diacerein, an antiosteoarthritic drug for enhancement in bioavailability and reduction in its side effects. J. Biomed. Nanotechnol., v.9, n.5, p.891-900, 2013.

JAIN, C.; VYAS, S. Preparation and characterization of niosomes containing rifampicin for lung targeting. $J$. Microencapsul., v.12, n.4, p.401-407, 1995.

KORCHOWIEC, B.; PALUCH, M.; CORVIS, Y.; ROGALSKA, E. A Langmuir film approach to elucidating interactions in lipid membranes: 1, 2-dipalmitoyl glycero3 phosphoethanolamine cholesterol metal cation systems. Chem. Phys. Lipids, v.144, n.2, p.127-136, 2006.

LI, F.T.; ZHAO, D.S.; LUO, Q.Z.; LIU, R.H.; YIN, R. Research on surface-modification of Nano-TiO2 by span $60 . J$. Ceram. Process. Res., v.9, n.4, p.398-400, 2008.

MAHALE, N.; THAKKAR, P.; MALI, R.; WALUNJ, D.; CHAUDHARI, S. Niosomes: novel sustained release nonionic stable vesicular systems-an overview. $A d v$. Colloid. Interface Sci., v.183-184, n.11, p.46-54, 2012. 
MANOSROI, A.; WONGTRAKUL, P.; MANOSROI, J.; SAKAI, H.; SUGAWARA, F.; YUASA, M.; ABE, M. Characterization of vesicles prepared with various nonionic surfactants mixed with cholesterol. Colloids Surf. B Biointerfaces, v.30, n.1-2, p.129-138, 2003.

MARIANECCI, C.; RINALDI, F.; MASTRIOTA, M.; PIERETTI, S.; TRAPASSO, E.; PAOLINO, D.; CARAFA, M. Anti-inflammatory activity of novel ammonium glycyrrhizinate/niosomes delivery system: human and murine models. J. Control. Release, v.164, n.1, p.17-25, 2012.

MASKI, N.; KUMARAN, A.; GIRHEPUNJE, K.; GHODE, P.; RANDIVE, S.; PAL, R. Studies on the preparation, characterization and solubility of $\beta$-cyclodextrin-diacerein inclusion complexes. Int. J. Pharm. Pharm. Sci., v.1, n.1, p.121-135, 2009.

MOAZENI, E.; GILANI, K.; SOTOUDEGAN, F.; PARDAKHTY,A.; NAJAFABADI, A.R.; GHALANDARI, R.; FAZELI, M.R.; JAMALIFAR, H. Formulation and in vitro evaluation of ciprofloxacin containing niosomes for pulmonary delivery. J. Microencapsul., v.27, n.7, p.618$627,2010$.

MUZZALUPO, R.; TAVANO, L.; TROMBINO, S.; CASSANO, R.; PICCI, N.; LA MESA, C. Niosomes from $\alpha, \omega$-trioxyethylene-bis (sodium 2-dodecyloxypropylenesulfonate): Preparation and characterization. Colloids. Surf. B Biointerfaces, v.64, n.2, p.200-207, 2008.

NGUYEN, M.; DOUGADOS, M.; BERDAH, L.; AMOR, B. Diacerhein in the treatment of osteoarthritis of the hip. Arthritis Rheum., v.37, n.4, p.529-536, 1994.

PARDAKHTY, A.; VARSHOSAZ, J.; ROUHOLAMINI, A. In vitro study of polyoxyethylene alkyl ether niosomes for delivery of insulin. Int. J. Pharm., v.328, n.2, p.130-141, 2007.
PEARLE, A.D.; WARREN, R.F.; RODEO, S.A. Basic science of articular cartilage and osteoarthritis. Clin. Sports Med., v.24, n.1, p.1-12, 2005.

REIS, O.; WINTER, R.; ZERDA, T.W. The effect of high extenal pressure on DPPC-cholesterol multilammellar vesicles: a pressure-tuning Fourier transform infrared spectroscopy. Biochim. Biophys. Acta, v.1279, n.1, p.5-16, 1996.

SHARI, M.L.; BATHON, J.M. Osteoarthritis: pathophysiology [Online]. 2012. The john hopkins arthritis center. Available at: <http://www.hopkinsarthritis.org/arthritis-info/ osteoarthritis/oa-pathophysiology/>. Accessed on: March 2014.

SILVERSTEIN, R.M.; WEBSTER, F.X.; KIEMLE, D.J. Spectrometric identification of organic compounds. 7.ed. New York: John Wiley \& Sons In, 2005. 512 p.

UCHEGBU, I.F.; DOUBLE, J.A.; TURTON, J.A.; FLORENCE, A.T. Distribution, metabolism and tumoricidal activity of doxorubicin administered in sorbitan monostearate (Span 60) niosomes in the mouse. Pharm. Res., v.12, n.7, p.10191024, 1995.

UCHEGBU, I.F.; VYAS, S.P. Non-ionic surfactant based vesicles (niosomes) in drug delivery. Int. J. Pharm., v.172, n.1, p.33-70, 1998.

WADDAD, A.Y.; ABBAD, S.; YU, F.; MUNYENDO, W.L.; WANG, J.; LV, H.; ZHOU, J. Formulation, characterization and pharmacokinetics of Morin hydrate niosomes prepared from various non-ionic surfactants. Int. J. Pharm., v.456, n.2, p.446-458, 2013.

YOSHIOKA, T.; STERNBERG, B.; FLORENCE, A.T. Preparation and properties of vesicles (niosomes) of sorbitan monoesters (Span 20, 40, 60 and 80) and a sorbitan triester (Span 85). Int. J. Pharm., v.105, n.1, p.1-6, 1994.

Received for publication on $25^{\text {th }}$ August 2014 Accepted for publication on $24^{\text {th }}$ June 2015 
